\title{
LABORATORY DECOMPOSITION OF DALBERGIA NIGRA ALL. EX. BENTH AND EUCALYPTUS GRANDIS W.HILL EX. MAIDEN LEAVES IN FOREST AND EUCALYPT PLANTATION SOILS ${ }^{1}$
}

\author{
Juliana L. P. Rezende ${ }^{2}$ \\ Queila S. Garcia ${ }^{2}$ \\ Maria Rita M. M. L. Scotti ${ }^{2}$
}

Recebido em 24/02/00. Aceito em 25/07/01.

\begin{abstract}
RESUMO - (Decomposição em laboratório de folhas de Dalbergia nigra e de Eucalyptus grandis em terra de mata e de eucaliptal). O objetivo foi acompanhar a decomposição de folhas de D. nigra e de E. grandis em laboratório, enterradas por 12 meses, em solo de Mata Atlântica e de eucaliptal com 40 anos de plantio. Os valores de $\mathrm{pH}$ obtidos para os solos de mata e de eucaliptal foram 5,61 e 4,47 e de alumínio 0,32 e 1,89mEqx100, respectivamente. Um grande número de microrganismos (fungos totais, solubilizadores de fosfato e de celulolíticos) foram encontrados no solo de mata. Uma perda de massa significativa foi observada após 4 meses de decomposição nas folhas de ambas espécies no solo de mata (30\%), enquanto em solo de eucaliptal esta perda foi observada somente após 8 meses (40\%). O conteúdo inicial de $\mathrm{N}$ e $\mathrm{P}$ em folhas de $D$. nigra é maior do que nas de E. grandis, embora os conteúdos de lignina e celulose sejam semelhantes. A razão $\mathrm{C} / \mathrm{N}$ é maior nas folhas do eucalipto, indicando que sua degradação deve ser lenta. Apesar disto, não foram observadas diferenças significativas nas taxas de decomposição entre os tratamentos. Ocorreu uma perda significativa de $\mathrm{P}$, lignina e celulose nos tratamentos. Estes resultados mostraram diferenças entre a decomposição de ambas as espécies e a influência do solo de mata e de eucaliptal no processo de decomposição.
\end{abstract}

Palavras-chave - Dalbergia, Eucalyptus, ciclagem, decomposição

\begin{abstract}
Laboratory decomposition of Dalbergia nigra and Eucalyptus grandis leaves in forest and eucalypt plantation soils). The objective was to evaluate the decomposition of D. nigra and E. grandis leaves under laboratory conditions when incubated in soils from Atlantic Forest and from a 40-year-old eucalypt plantation for a year. The obtained values of $\mathrm{pH}$ in forest and eucalypt plantation soils were 5.61 and 4.47 and for aluminum 0.32 and $1.89 \mathrm{mEqx} 100$, respectively. A great number of microorganisms (total fungi, phosphate solubilising and cellulolytic organisms) were found in forest soil. Litterbag study revealed a higher mass loss of the leaves in forest soil in the first four months (c. 30\%). In the eucalypt plantation soils loss was observed only after eight months (c. 40\%). The initial contents of $\mathrm{N}$ and $\mathrm{P}$ were greater in D. nigra than in E. grandis leaves, although lignin and cellulose contents were similar. The $\mathrm{C} / \mathrm{N}$ ratio was higher in $E$. grandis indicating that its degradation could be slower. Nonetheless, there were no significant differences in the decay rates $(\mathrm{k})$ among the treatments. Phosphorus, lignina and cellulose were lost at the end of the experiment in all treatments. The results show the differences between decomposition of both species and the influence of forest and eucalypt plantation soils in the decomposition process.
\end{abstract}

Key word - Dalbergia, Eucalyptus, nutrient cycling, decomposition

\footnotetext{
${ }^{1}$ Trabalho de monografia da primeira autora

${ }^{2}$ Depto Botânica, ICB, Universidade Federal de Minas Gerais. CP: 486, CEP: 30.161-970. Belo Horizonte, MG, Brasil

E-mail: queila@dedalus.lcc.ufmg.br
} 


\section{Introduction}

The cycling of nutrients in the ecosystems is one of the principal processes that support organic matter production. The rates and pathways of litter decomposition are determined by the climate, the quality of the substrate and the composition of the decomposer community (Swift et al. 1979). Two phases are also recognized in this process: the transfer of more soluble compounds to the soil, as $\mathrm{C}$ and $\mathrm{N}$, which are progressively mineralized or immobilized and the humification of lignin and cellulose (Coûteaux et al. 1995).

Soil type and the substrate quality are cardinal factors that determine litter decomposition and the kind of humus formed. These two factors select the microflora, determining the formation of the soil organic matter (Coleman et al. 1989; La Caro \& Rudd 1985; Bargali et al. 1993).

Substrate can influence the decay rate in many ways. Species with low values of the $\mathrm{C} / \mathrm{N}$ ratio decompose faster than species with higher $\mathrm{C} / \mathrm{N}$ values; also lignin/ $\mathrm{N}$ exerts control over the rate of decomposition (Mellilo \& Aber 1982). Although high $\mathrm{N}$ concentration speeds decomposition, high contents of lignin and polyphenolics can delay and also inhibited this process (Meentemeyer 1978; Coulson et al. 1960; Palm \& Sanchez 1991). In the first phase of decomposition, elements, which are readily utilized by the microorganisms, like $\mathrm{N}$ and $\mathrm{P}$ could be immobilized in microbial biomass (Berg and McClaugherty 1989; Coûteaux et al. 1995; Songwe et al. 1995).

Litter decomposition rate varies between leguminous trees and eucalypt species (Sankaran 1993; Bernhard-Reversat 1993). An extensive literature deals with the impact of the eucalypt monoculture on soils (Bargali et al. 1993), cycling of nutrients (Sankaran 1993; Bernhard-Reversat 1993), inhibition and competition with native vegetation (De Moral \& Muller 1970), and also with allelopathic effect on soil microbial activity, as well as on legume tree nodulation (Moura et al. 1996). The Brazilian rosewood (Dalbergia nigra) is an endangered legume tree species that occurs in Atlantic Forest and is largely found at Parque Estadual do Rio Doce (PERD) the largest preserved area of ecosystem in Minas Gerais State (MG). Recent estimates indicate that $93,9 \%$ of the original vegetation of the Atlantic Forest in MG has been removed, making way for urban areas, agricultural expansion, pastures and mainly eucalyptus plantations for coke and pulp production (Machado 1995). Thus, our aim was to follow up under laboratory conditions the leaf decomposition of Dalbergia nigra and of Eucalyptus grandis, when incubated in soils from the Atlantic Forest (PERD) and from a eucalypt plantation. The in vitro comparison and evaluation of the decomposition process between these species will give us some preliminary information about the rates and pathways of the decomposition and the release of nutrients of both species in their native soils.

\section{Material and methods}

The soil samples used in this study came from a stretch of the Atlantic Forest and from a 40-year-old eucalypt plantation. Until 1960 this eucalypt area was a gallery forest presenting many species of silvicultural tracts. After 1960 the gallery forest started a process of change when eucalypt plantations were introduced to the area. Intensive eucalypt plantations cover the whole region today.

Three replicates of each soil type (topsoil 0-10 cm) were analyzed for aluminium (Defelipo \& Ribeiro 1981) and pH (in water) (Raij \& Quaggio 1983). Using the dilution plate technique the total fungi, phosphate solubilising microorganisms (Arora \& Gauir 1979) and cellulolytic organisms (Pramer et al. 1964) were isolated from the soils.

A mixture of mature and senescent leaves were hand picked from some trees of Dalber- 
gia nigra Allemão ex. Benth (Leguminosae) and of Eucalyptus grandis W. Hill ex. Maiden (Myrtaceae) at the Campus of Minas Gerais State University and at an eucalypt plantation, respectively. We use only leaflets of $D$. nigra to avoid lignified rachises in the decomposition dynamics. These leaves were dried at $60^{\circ} \mathrm{C}$ till constant weights.

Litterbags (mesh size $1 \mathrm{~mm}$ ) were made for each species receiving $3 \mathrm{~g}$ of $D$. nigra leaflets or $E$. grandis leaves. The litterbags were incubated in 4 metal trays (two duplicates of each soil) containing $4.5 \mathrm{~kg}$ of forest or eucalypt soil (described above). Eight litterbags of both species were buried in each tray. These trays were wrapped in plastic and keep under laboratory conditions at $25 \pm 2{ }^{\circ} \mathrm{C}$. The soils were watered every week to maintain the moisture level at 60 $70 \%$ water holding capacity. We evaluated the initial chemical composition (total N, P, lignin and cellulose) of the dried leaves of D. nigra and of E. grandis. Every 4 months, five litterbags per species were collected from the trays and cleaned. They were dried at $60^{\circ} \mathrm{C}$ until weight stabilization. After drying, the litterbags were weighed and the mass loss percentage was determined. Samples were milled in a laboratory mill equipment, and were analyzed for total contents of N, P, lignin and cellulose. The total $\mathrm{N}$ was determined by the colorimetric method using Nessler solution (Oliveira 1986). For phosphorus the ascorbic acid method was used (Silva 1981). The total organic matter was estimated as loss-on-ignition after incineration of a known mass at $500^{\circ} \mathrm{C}$ for two hours. The carbon contents was estimated as Wesemael (1993). The structural components, lignin and cellulose, were obtained by the acid detergent fiber method (van Soest 1963).

Remaining mass in the litterbags (\%RM) and the remaining amount of mineral and organic nutrients were calculated as percentage of initial amount (Wesemael 1993). The annual decomposition rate of leaves was estimated following the exponential decay model (Olson
1963): $\operatorname{Ln}\left(X_{t} / X_{0}\right)=-k t$, where, Ln represents the natural logarithm, $X_{t}$ is the remaining mass at each period of time, $X_{0}$ is the initial mass and $t$ is time in years. The half-life of leaves, the theoretical time required for decomposition of $50 \%$ of the mass was obtained following the model by Olson (1963). The differences between the treatments was obtained by Tukey test with $\mathrm{P}<0.05$ after application of simple variance analyses (ANOVA). In figures letters compares the variances only after 12 months of decomposition among the treatments. The repeated letters indicate the same level of significance among the treatments.

\section{Results and discussion}

The soils used in this study differ in their chemical and biological characteristics (Tab. 1).

In the soil from eucalypt plantation $\mathrm{pH}$ is lower, the aluminium content is almost $83 \%$ higher, and all the microorganisms studied (specially the phosphate solubilizing organisms) appear in reduced number when compared to forest soil.

The abundance associated with the kind of microorganisms present in the soils can influence the decomposition, once they have a specialized apparatus (such as extracellular enzymes) to degraded soluble and recalcitrant substances from plant material (Hodgkiss \& Vrijmoed 1992; Joshi et al. 1993 and Lang et al. 1997). The initial chemical composition of $D$. nigra and E. grandis leaves is given on table 2. The $\mathrm{N}$ and $\mathrm{P}$ concentrations in the leguminous leaves were almost two-fold higher than in $E$. grandis leaves.

The contents of lignin and cellulose were similar in both species. In E. grandis was observed the highest value of $\mathrm{C} / \mathrm{N}$ ratio.

A significant mass loss $(\mathrm{P}<0.001)$, in the first four months, was observed for D. nigra and E. grandis incubated in forest soil (approximately $30 \%$ ); in the eucalypt soil, a significant reduction in mass (c. 40\%) was observed only 
Table 1. Chemical and biological composition of forest and eucalypt plantation soils. Letters compares values in the same line. (* $\mathrm{P}<0.05)$.

Parameters

$\mathrm{pH}$

Aluminium (mEq x 100)

Total fungi (cels/g dry weight)

Phosphate solubilising (cels/g dry weight)

Cellulolytic organisms (cels/ml)
Forest soil

Eucalypt soil after eight months of incubation $(\mathrm{P}<0.001)$ (Fig.1). In these phases could have occurred the loss of soluble and easily decomposable compounds, which characterizes the first phase of decomposition (La Caro \& Rudd 1985; Songwe et al. 1995).

Soon after there was a tendency to stabilization in mass loss. The breakdown of more complex molecules into more simple compounds, as sugar, aminoacids as well as lignocellulose material (La Caro \& Rudd 1985) could have inhibited the rapid mass loss. Meguro et al. (1980) studying the decomposition of leafs of some native trees in a secondary semideciduos forest at southeast Brazil, also show that the rate of decomposition decreases with increasing decomposition time.

At the end (12 months), we observed an increase in the remaining mass of $D$. nigra in eucalypt soil. This is a common fact in studies
5.61
$4.47 *$
0.32
$1.89 *$
$1.90 \times 10^{7}$
$0.45 \times 10^{7 *}$
$4.50 \times 10^{5}$
$0.59 \times 10^{5 *}$
$2.50 \times 10^{3}$
$1.10 \times 10^{3 *}$

using the litterbag technique, once it is retrieved a different litterbag each time (see Suffling \& Smith 1973 for more details on this technique). Others authors also relates these increase to invasion of some micro and meso animals into the bag (Songwe et al. 1995; Swift et al. 1979).

The percentage of remaining mass at the end of the experiment was higher than $50 \%$. The annual rate of decomposition ( $\mathrm{k}$ ), was low and the half-life $\left(\mathrm{T}_{1 / 2}\right)$ of leaves, was high and both had no significant differences among the treatments (Tab. 3). Sankaran (1993) studying the decomposition of Albizia falcataria and of Eucalyptus terenticonis in field and laboratory in India, found that under laboratory conditions the process is slower than in field. He found a $\mathrm{k}$ value in field of 1.67 and $\mathrm{T}_{1 / 2}$ of 5.0 for the legume species while in laboratory 0.97 and 8.6 respectively. For E. terenticonis the values of $\mathrm{k}$ and $\mathrm{T}_{1 / 2}$ in field were $0.74-11.2$ and in labora-

Table 2. Initial chemical composition of D. nigra and E. grandis leaves

\begin{tabular}{|c|c|c|c|c|c|c|}
\hline \multirow[t]{2}{*}{ Species } & \multicolumn{4}{|c|}{$\begin{array}{l}\text { Concentration } \\
\text { mg. } \mathrm{g}^{-1} \text { dry weight }( \pm \mathrm{SD})\end{array}$} & \multirow[t]{2}{*}{$\mathrm{LOI}^{1}$} & \multirow[t]{2}{*}{$\mathrm{C} / \mathrm{N}^{2}$} \\
\hline & $\mathrm{N}$ & $\mathrm{P}$ & Lignin & Cellulose & & \\
\hline D. nigra & $11.9 \pm 0.1$ & $2.4 \pm 0.2$ & $40 \pm 1.4$ & $32 \pm 0.3$ & 97 & 41 \\
\hline E. grandis & $6.3 \pm 0.6$ & $1.6 \pm 0.1$ & $37 \pm 0.9$ & $33 \pm 2.6$ & 96 & 76 \\
\hline
\end{tabular}

${ }^{1}$ Loss on ignition at $500^{\circ} \mathrm{C}(\%)$

${ }^{2}$ Carbon content $=\left(\right.$ LOI x 10) $/ 2\left(\mathrm{mg} \mathrm{g}^{-1}\right.$ dry matter $)$ 
Table 3 - Annual rate of decomposition (k) and half-life $\left(\mathrm{T}_{1 / 2}\right)$ in months of D. nigra and $E$. grandis leaves incubated in forest and eucalypt plantation soil (No significance at $\mathrm{P}<0.05$ ).

\begin{tabular}{lcc}
\hline Specie/soil & $\mathrm{k}$ & $\mathrm{T}_{(1 / 2)}$ \\
\hline D. nigra / forest & 0.44 & 19.9 \\
D. grandis / forest & 0.47 & 18.45 \\
E. grandis / eucalypt & 0.59 & 14.09 \\
E. nigra / eucalypt & 0.46 & 18.56 \\
\hline
\end{tabular}

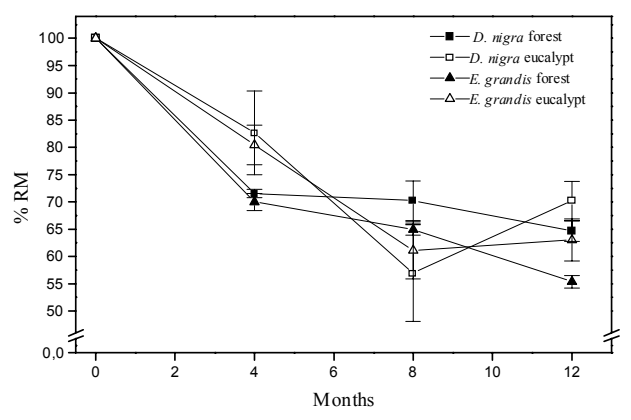

Figure 1 - Remaining mass in D. nigra and E. grandis leaves incubated in forest and eucalypt plantations soils. Bars represent the standard error (SE).

tory $0.54-15.5$ respectively. in tropical forests, $\mathrm{k}$ of many species varied between 0.64 and 1.54 in Puerto Rico (La Caro \& Rudd 1985) and in studies in Niger the means k was 2.51 (Songwe 1993), both under field conditions. Studies with species from temperate regions showed values of $\mathrm{k}$ from 0.13 to 0.50 in experiments conducted in field (Wesemael 1993; Moro et al. 1996). Our results presented $k$ and $T_{1 / 2}$ values closer to those obtained in the experiments in laboratory and under field conditions in temperate regions.

The nutrients go through the following three phases during decomposition: leaching, bioaccumulation (immobilization) and release (Swift et al. 1979). This author also relates that leaching and/or accumulation may precede final release depending on the initial physical and chemical properties of the litter, the physical environmental and the decomposer activity. Elements such as $\mathrm{N}$ and $\mathrm{P}$ maybe first immobi- lized in microorganisms tissues and are only released when the critical concentration is reached (Berg \& McClaugherty 1989). Some compounds like polyphenolics can interfere in $\mathrm{N}$ release from plant tissues (Coulson et al. 1960), once they form resistant complexes that can slow degradation (Valis \& Jones 1973).

The remaining amounts of $\mathrm{N}$ in D. nigra in forest soil increased during decomposition (Fig. 2 ). The leaves of $E$. grandis incubated in forest soil showed a reduction in $\mathrm{N}$ contents at four months, followed by an increase at eight months, although being the final concentration (12 months) similar to the initial concentration. In the eucalypt plantation soils, the remaining amounts of $\mathrm{N}$ in both species were similar all over the process. These results show a strong influence of the soil and suggest an influence of eucalypt leaves in the dynamics of this element.

The initial loss of $\mathrm{P}$ in the leaves of both species in both soils could be due to leaching. Accentuated accumulation occurred after this, being higher and statistically similar for $D$. $n i$ gra in both soils (Fig. 2). For E. grandis, this accumulation was higher in forest soil than in eucalypt plantation soil, showing a strong influence from the kind of soil. After 12 months, all treatments showed a release of $\mathrm{P}$, but this did not exceed $50 \%$ of the remaining amount of this nutrient.

Cellulose decreased, but without significant differences, in all treatments after 12 months. This decrease was approximately $55 \%$ for $D$. nigra in both soils and $45 \%$ of the initial concentration for E. grandis in both soils (Fig. 2).

The leaves of $E$. grandis incubated in both soils and of $D$. nigra incubated in eucalypt plantation soil showed a reduction of $40 \%$ in the lignin content during decomposition, while in forest soil $D$. nigra leaves showed a decrease of ca. $25 \%$ in this compound (Fig. 2). Due to the resistance of lignin, its degradation is usually slow and there may be an increase in its concentration as the depolimerization proceeds and 


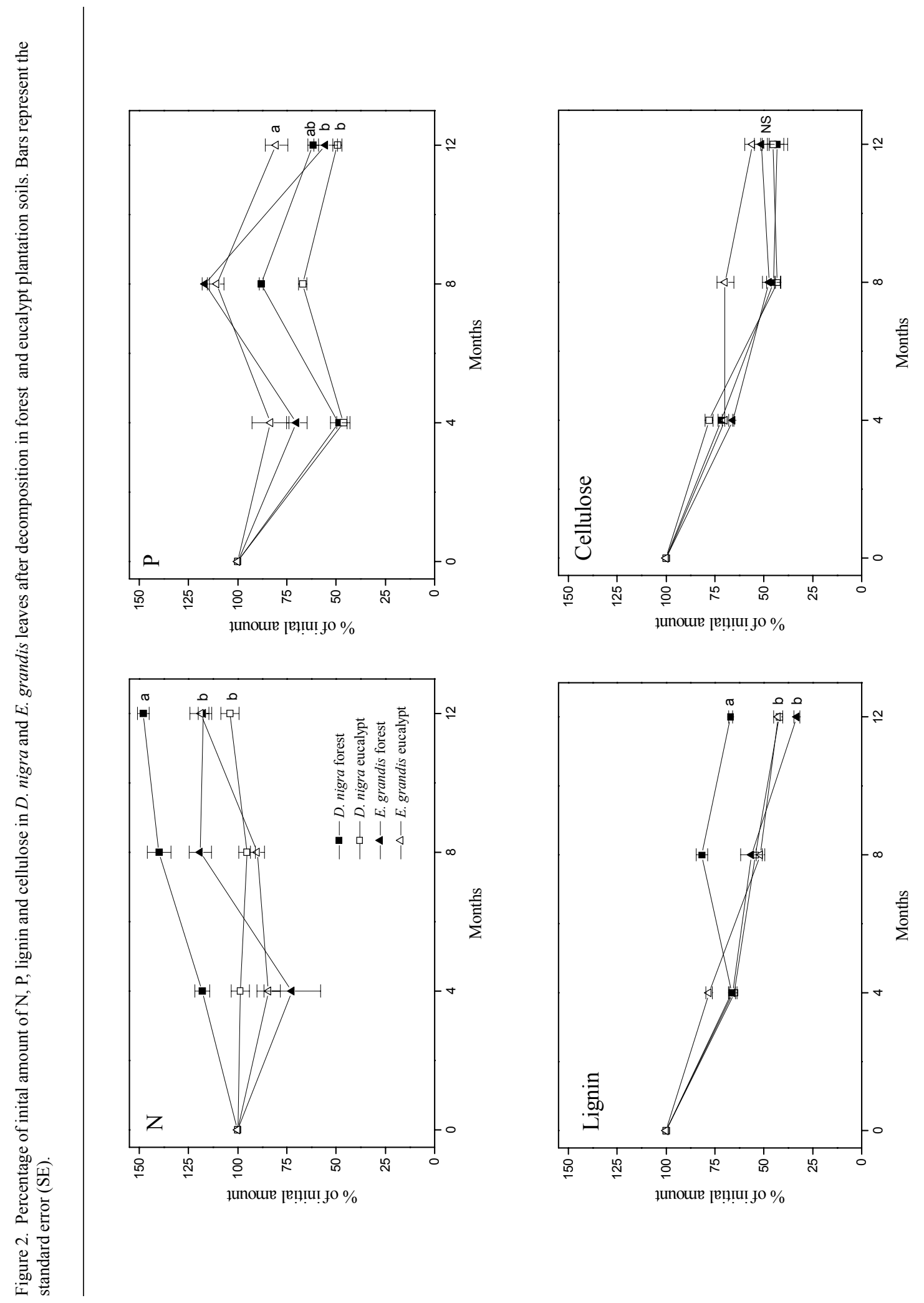


humic acids are formed (Berg \& McClaugherty 1989; Coûteaux et al. 1995). These differences reveal the influence of soils and substrate characteristics in the decomposition process.

After 12 months of incubation all treatments showed a remaining amount of $\mathrm{P}$, lignin and cellulose of $40-50 \%$ approximately (except lignin in D. nigra in forest soil, $75 \%$ - Fig. 2). Only N had its concentration up to $100 \%$. Berg \& McClaugherty (1989) in a long-term study found that during early stages of decay concentrations of N, P and lignin in the litter increase.

They have also found out that release of $\mathrm{N}$ and $\mathrm{P}$ occurred after the onset of a net disappearance of lignin and consequently later during the decay process. Mellilo \& Aber (1982) also relates that humus compounds that are formed during decomposition can have a large amount of $\mathrm{N}$ bound to it, and since humus compounds are relatively resistant to decomposition, the $\mathrm{N}$ bound in humus compounds will be released slowly. We can expeculate that mineral nutrients, especially $\mathrm{N}$, in our study would have its concentrations reduced only after a great release of the lignocellulolitic compounds.

Decomposition is a very complex process under field conditions and it is important to understand the limitations of in vitro essays (Anderson 1993). In our study, the decomposition rate were lower when compared to the process in field in tropical forests (e.g. La Caro \& Rudd 1985; Songwe 1993). Besides this, the kinds of soils used here, with different properties could have contributed to arise the differences in decomposition.

There are evidences that the older plantations of Eucalyptus cause a chemical and biological degradation to soils (Bargali et al. 1993), what corroborate our results, once the eucalypt soil used in this study comes from an eucalypt plantation over 40 years old and had its physical, chemical and biological characteristics very different from those observed in forest soil.

\section{Acknowledgements}

We thank $\mathrm{CNPq}$ and PrPq (from Universidade Federal de Minas Gerais), for financial support. We also thank Márcio Rezende for reviewing the English version and the Journal referees for the review and suggestions made to the manuscript.

\section{References}

Anderson, J.M. 1993. Decomposition. In: G.A.F. Hendry \& J.P. Grine (Eds), Methods in comparative plant ecology - a laboratory manual.. Chapman \& Hall. New York.

Arora, D. \& Gauir, A. C. 1979. Solubilization of different inorganic phosphates. Indian Journal Experience Biology. vol. 17

Au, D.W.T.; Hodgkiss, I.J. \& Vrijmoed, L.L.P. 1992. Fungi and cellulolityc activity associated with decomposition of Bauhinia purpurea leaf litter in a polluted and unpolluted Hong Kong waterway. Cannadian Journal of Botany 70: 1071-1079.

Bargali, S. S.; Singh, S.P. \& Singh, R. P. 1993. Patterns of weight loss and nutrient release from decomposing leaf litter in an age series of eucalypt plantation. Soil Biology Biochemistry 25: 1731-1738.

Berg, B. \& McClaugherty, C. 1989. Nitrogen and phosphorus release from decomposing litter in relation to the disappearance of lignin. Canadian Journal of Botany 67: 1148-1156.

Bernhard-Reversat, F. 1993. Dynamics of litter and organic matter at soil - litter interface in fast - growing tree plantations on sandy ferralic soils (Congo). Acta Oecologica 14: 179-195.

Coleman, D.C.; Oades, J. \& Uehara, G. 1989. Dynamics of soil organic matter in tropical ecosystems. NifTAL Project University of Hawaii Press.

Coulson, C. B.; Davies, R.I. \& Lewis, D. A. 1960. Polyphenols in plant, humus, and soil-I. Polyphenols of leaves, litter, and superficial humus from mull and mor sites. Journal of Soil Science 11: 20-29.

Coûteaux, M. M.; Bottner, P. \& Berg, B. 1995. Litter decomposition, climate and litter quality. Trends in Ecology and Evolution 10: 63-66.

Defelipo, B. V. \& Ribeiro, A. C. 1981. Análise química do solo (metodologia). Boletim de extensão 29, UFV, Viçosa, MG. 
De Moral, R. \& Muller, C.H. 1970. The allelopathic effects of Eucalyptus calmadulensis. American Midland Nature Notre Dame 83: 160-200.

Joshi, S.R; Sharma, G.D. \& Mishra, R.R. 1993. Microbial enzyme activities related to litter decomposition near a highway in a sub-tropical forest of north east India. Soil Biology and Biochemistry 25: 1763-1770.

Lang, E; Eller, G \& Zadrazil, F. 1997. Lignocellulose decomposition and production of lignolytic enzymes during interaction of white rot fungi with soil microorganisms. Microbial Ecology 34: 1-10.

La Caro, F. \& Rudd, R. L. 1985. Leaf disappearance rates in Puerto Rican Montane rain forest. Biotropica 17: 269-276.

Machado, R.B. 1995. Padrão de fragmentação da Mata Atlântica em três municípios da Bacia do Rio Doce (Minas Gerais) e suas consequências para a avifauna. Dissertação de Mestrado. Universidade Federal de Minas Gerais, Belo Horizonte, MG, Brasil.

Meentemeyer, V. 1978. Macroclimate and lignin control of litter decomposition rates. Ecology 59: 465 472.

Mellilo, J. M. \& Aber, J. D. 1982. Nitrogen and lignin control of hardwood leaf litter decomposition dynamics. Ecology 63: 621-626.

Moura, U. T. L.; Marques, M.S.; Gonçalves, L. M. B.; Scotti, M.R.M.M.L.; Valle M. T. S \& Lemos-Filho, J. P. 1996. Nodulação e crescimento de leguminosas cultivadas em solos coletados sob eucaliptal e sob Mata Atlântica: relação com os efeitos alelopáticos do Eucalyptus. Revista Brasileira de Ciência do Solo 20: 399-405.

Oliveira, S.A. 1986. Método simplificado para determinação colorimétrica de nitrogênio em plantas. Ciência e Cultura 38: 178-180.

Olson, J.S. 1963. Energy storage and the balance of producers and decomposers in ecological systems. Ecology 44: 322-331.

Palm, C. A. \& Sanchez, P. A. 1991. Nitrogen release from the leaves of some tropical legumes as affected by their lignin and polyphenolic contents. Soil Biology Biochemistry 23: 83-88.

Pramer, D. \& Schimidt, E.L. 1964. Experimental soil microbiology. Minneapolis Burguess.

Raij, B. V. \& Quaggio, J. A. 1983. Métodos de análise de solo para fins de fertilidade. Boletim Técnico81. Instituto Agronômico de Campinas.

Sankaran, K. V. 1993. Decomposition of leaf of albizia (Paraserianthes falcataria), eucalypt (Eucalyptus tereticornis) and teak (Tectona grandis) in Kerala,
India. Forest Ecology and Management 56: 225242.

Silva, D. J. 1981. Determinação inorgânica de P. In: Análise de alimentos (métodos químicos e biológicos). Viçosa, UFV. 165 p.

Songwe, N.C.; Okali, D.U.U. \& Fasehun, F.E. 1995. Litter decomposition and nutrient release in a tropical rainforest, Southern Bakundu Forest Reserve, Cameroon. Journal of Tropical Ecology 11: 333 350.

Swift, M.J.; Heal, O.W. \& Anderson, J.M. 1979. Decomposition in terrestrial ecosystems. Blackwell Scientific Publications, London, 371 pp.

Suffling, R. \& Smith, D.V. 1974. Litter decomposition studies using mesh bags: spillage inaccuracies and the effects of repeated artificial drying. Cannadian Journal of Botany 52: 2157-2163

Vallis, I. \& Jones, R.J. 1973. Net mineralization of nitrogen in leaves and leaf litter of Desmodium intortum and Phaseolus atropurpureus mixed with soil. Soil Biology Biochemistry 5: 391-398.

Van Soest, P.J. 1963. Use of detergents in the analysis of fibrous feeds II. A rapid method for the determination of fiber and lignin. Journal Association Official Agronomy Chemistry 46: 829-835

Wesemael, B. V. 1993. Litter decomposition and nutrient distribution in humus profiles in some Mediterranean forests in southern Tuscany. Forest Ecology and Management 57: 99-114. 